\title{
The Formation of a Crystalline Oxazolidin-5-one from (L)-Alanine and its Use as a Chiral Template in the Practical Synthesis of $\alpha$-Substituted Alanine Esters
}

\author{
Magnus Eriksson*, Elio Napolitano, Jinghua Xu, Suresh Kapadia, Denis Byrne, Laurence Nummy, \\ Nelu Grinberg, Sherri Shen, Heewon Lee, and Vittorio Farina
}

\begin{abstract}
Three different protocols to synthesize oxazolidin-5-ones have been studied with the goal to develop a method to synthesize a diastereomerically pure oxazolidin-5-one. A novel method is reported that uses a dynamic crystallization-induced asymmetric transformation to isolate a single diastereomer of an oxazolidin-5-one in $92 \%$ yield on kilogram scale. Alkylation of the oxazolidin-5-one template leads to good-to-excellent yields of $\mathrm{N}$-protected $\alpha$-substituted alanine esters in $>98-99 \%$ ee.
\end{abstract}

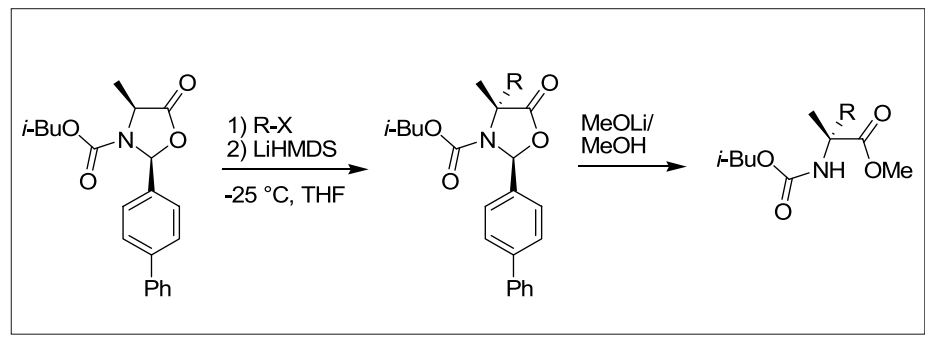

Keywords: Crystallization-induced asymmetric transformation · Diastereoselective alkylation · $\alpha, \alpha$-Disubstituted amino acid · Oxazolidin-5-one

${ }^{\star}$ Correspondence: Dr. M Eriksson Department of Chemical Development Boehringer Ingelheim Pharmaceuticals Inc. P.O. Box 368

Ridgefield, CT 06877, USA

Tel.: +1 2037984056

Fax: +1 2038374056

E-Mail: eriksson@rdg.boehringer-ingelheim.com

\section{Introduction}

The subject of nonproteinogenic $\alpha$-amino acids has been an area of growing interest in recent years. Substituted $\alpha$-amino acids have been used in research in several areas, notably peptidomimetics, protein synthesis, natural products synthesis and in the synthesis of pharmaceutically interesting compounds [1].

Our interest in the synthesis of $\alpha, \alpha$ disubstituted amino acids stems from a research program on protein-protein interactions [2] and more specifically on smallmolecule inhibitors of cell-cell interactions between leukocyte function-assisted antigen (LFA-1) and intercellular adhesion molecule (ICAM-1). This research led to the discovery of a potent LFA-1 inhibitor, BIRT 377 (1) shown in Scheme 1 [3].

Retrosynthetically, $\mathbf{1}$ can be derived from the chiral $\alpha, \alpha^{\prime}$-disubstituted amino acid 2 . There are a number of protocols available for synthesis of these compounds and these methods have been reviewed [4]. Of particular relevance to this work are methods based on alkylation of chiral templates, and examples can be found in the work by the groups of Schöllkopf [5], Williams [6], and Seebach [7] (Scheme 2).

The synthesis of $\mathbf{2}$ was envisioned via the procedure oftentimes referred to as Self-Reproduction of Chirality (SROC) which was initially developed by Seebach et al. [8]. Its key feature is the diastereoselective alkylation of stereochemically defined imidazolidinones or oxazolidinones Thus, deprotonation at the $\alpha$-position followed by alkylation gives $\alpha, \alpha^{\prime}$-disubstituted imidazolidinones or oxazolidinones. Since the alkylation is highly stereospecific, one is able to isolate chiral $\alpha, \alpha^{\prime}$-disubstituted amino acids of high enantiomeric purity after hydrolysis/deprotection of the imidazolidinone/oxazolidinone ring. The key to the success of this protocol is the ability to prepare 2-substituted imidazolidinones or oxazolidinones from chira 


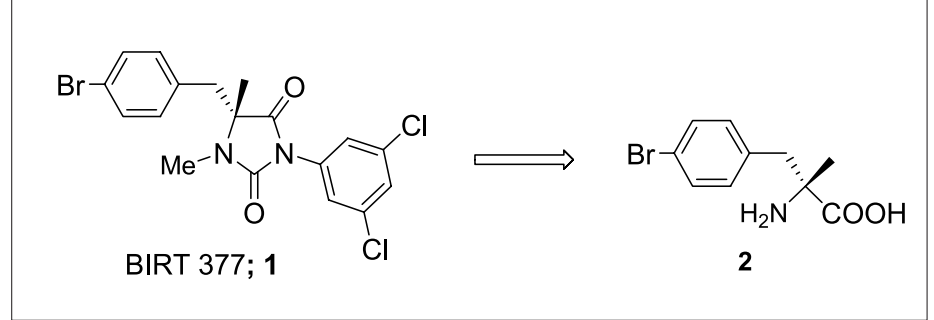

Scheme 1. Retrosynthetic analysis of BIRT-377

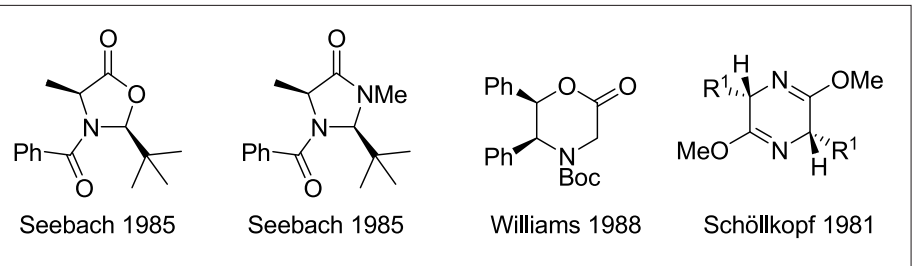

Scheme 2. Chiral templates used for the synthesis of $\alpha, \alpha^{\prime}$-disubstituted amino acids

amino acids and to obtain these templates as pure diastereomers in high yield. Using the imidazolidinone approach, two routes to BIRT 377 starting from Boc-protected (D)-alanine were developed [9-11]. However, a route via a diastereomerically pure oxazolidinone seemed more attractive due to a potentially easier hydrolysis of the intermediate alkylated template and also the possibility of using cheap (L)-alanine as starting material for the synthesis of $\mathbf{1}$, as opposed to its (D)-enantiomer, which is required in our previous approach [9]. To this end, we have communicated two protocols using oxazolidinones as templates for $\alpha$-alkylation to make chiral quaternary amino acids [12][13]. In this paper, we report further details of our work and, more precisely, we describe our attempts at gaining some insight into the mechanisms of the different methods to make oxazolidinones.

\section{Results and Discussion}

\section{Acylation of Imines}

We were initially interested in applying the Seebach protocol for the generation of the oxazolidinone template. The generic Seebach protocol is shown in Table 1 and consists of acylation of an imine salt, such as 3, made from an aromatic or aliphatic aldehyde and a sodium salt of an amino acid. Table 1 shows some examples from the literature based on (L)-alanine.

Evident from these results is the wide variation in cis:trans ratios and the sometimes low yield obtained. Particularly intriguing is the switch in diastereoselectivity of $\mathbf{4}$ in going from the alkylimine $(\mathbf{4 a}, \mathrm{R}=$ $t-\mathrm{Bu})$ to the aryl imine $(\mathbf{4} \mathbf{b}, \mathrm{R}=\mathrm{Ph})$. It is also unclear from these results whether the reported cis:trans ratios reflect thermodynamic or kinetic compositions.

In our hands, treatment of $3 \mathrm{a}(\mathrm{R}=t-\mathrm{Bu})$ with benzoyl chloride at reflux gave $\mathbf{4 a}$ in

Table 1. Data collected from the literature for cis:trans ratios of oxazolidinones

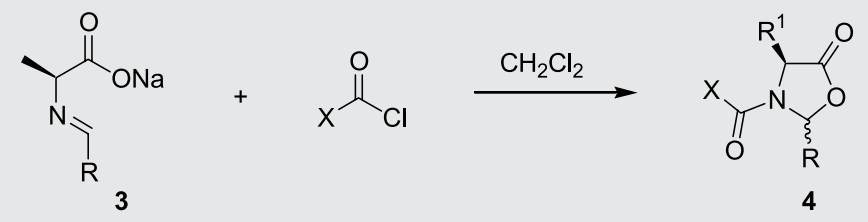

\begin{tabular}{cccccc} 
Entry & $\mathbf{R}$ & $\mathbf{X}$ & Cis:Trans & Yield of 4 [\%] & Ref. \\
\hline $\mathrm{a}$ & $t-\mathrm{Bu}$ & $\mathrm{Ph}$ & $5: 1$ & 92 & {$[7 \mathrm{a}]$} \\
$\mathrm{b}$ & $\mathrm{Ph}$ & $\mathrm{Ph}$ & $1: 7.5$ & 94 & {$[14]$} \\
$\mathrm{C}$ & $\mathrm{Ph}$ & $\mathrm{BnO}$ & $1: 2.5$ & 31 & {$[15]$} \\
$\mathrm{d}$ & $\mathrm{Ph}$ & $\mathrm{Ph}$ & trans only & 50 & {$[16]$} \\
$\mathrm{e}$ & Ferrocenyl & $t$-Bu & cis only & 95 & {$[17]$}
\end{tabular}

a 2:1 ratio of cis and trans oxazolidinones, lower than the 5:1 ratio reported by Seebach and Fadel [7a]. On the other hand, acylation of $3 \mathbf{b}(\mathrm{R}=\mathrm{Ph})$ gave $\mathbf{4 b}$ in 1:7.3 ratio of cis and trans diastereomers, similar to the 1:7.5 reported by Fadel and Salaün [14].

During our studies we have found that $\mathrm{N}$-acyloxazolidinones cis-4a and trans-4b easily undergo epimerization at $\mathrm{C}(2)$ when exposed to acidic reagents such as $\mathrm{ZnCl}_{2}$ in dichloromethane to produce a $60: 40$ mixture of cis and trans-4a $(22 \mathrm{~h})$ or $\mathbf{4 b}(2 \mathrm{~h})$ when stirred at rt. The same ratios can be obtained starting from trans-4a and cis-4b diastereomers. These results clearly indicate the thermodynamically preferred composition for $\mathbf{4 a}$ and $\mathbf{4 b}$ and the ratios reported by Seebach and Fadel [7a] and Fadel and Salaün [14] therefore represent mixtures obtained under non-thermodynamic conditions (Scheme 3).

Unfortunately, this protocol turned out to be less suitable on larger scale due to operational difficulties. We found the Na-salt of (L)-alanine to be very hygroscopic and prone to forming a thick oil. Its conversion to the Schiff base under heterogeneous conditions in pentane or higher hydrocarbons was plagued by long reaction times and erratic results and the acylation of the imines gave products with variable cis:trans ratios. We therefore decided to search for alternative methods to prepare diastereomerically pure oxazolidinones.

\section{Cyclization Promoted by $\mathrm{SOCl}_{2}$ and $\mathrm{ZnCl}_{2}$}

In our search of alternative condensation methods to make oxazolidinones, we attempted to use a one-step procedure by Karady et al. [18] In this protocol, N-Cbz(L)-phenylalanine was condensed with 2 equiv. benzaldehyde in the presence of 1 equiv. $p$-TsOH to obtain a 9:1 cis:trans mixture of oxazolidinones in $40 \%$ yield. This procedure was later modified by Cheng et al. [19] and their approach was to react $\mathrm{N}-\mathrm{Cbz}$-(L)-phenylalanine (5) with benzaldehyde dimethyl acetal (6) in the presence of $\mathrm{BF}_{3} \bullet \mathrm{Et}_{2} \mathrm{O}$ to afford oxazolidinone 7 (Scheme 4). A similar protocol was used by Schrader and Marlowe [20] using N-Cbz(L)-alanine to obtain the cis-oxazolidinone in $75 \%$ yield after crystallization.

We sought alternative reaction conditions for this protocol because we eventually wanted to implement this on a larger scale and therefore wanted to avoid the use of corrosive $\mathrm{BF}_{3} \bullet \mathrm{Et}_{2} \mathrm{O}$ and flammable diethyl ether as solvent. The low temperature condition was also a concern on large scale. Several Lewis acids were evaluated but neither gave any cyclized product. Only $\mathrm{ZnCl}_{2}$, $\mathrm{ZnBr}_{2}$ or $\mathrm{TiCl}_{4}$ gave oxazolidinone 9 in appreciable yield (Table 2 ).

During this work, we became aware of 


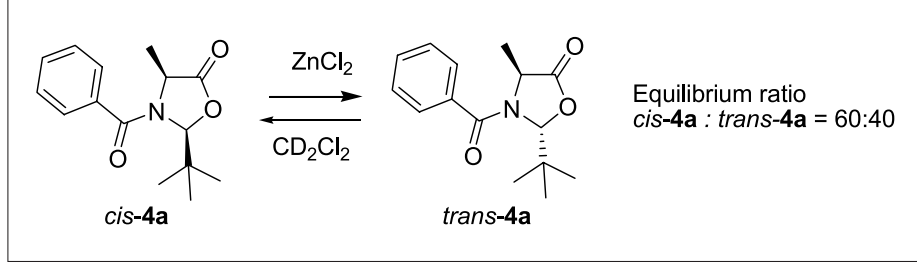

Scheme 3. Equilibration of cis- and trans-N-benzoyl oxazolidinone

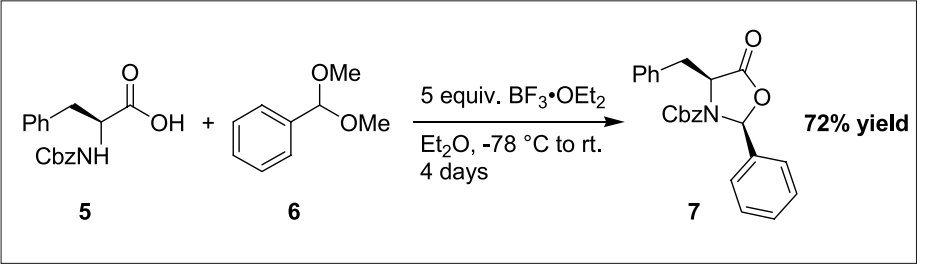

Scheme 4. Protocol used by Cheng et al. [19]

a report by Micheel and Meckstroth [21] where catalytic amounts of $\mathrm{SOCl}_{2}$ were used to affect the cyclization of glycine and aldehydes to oxazolidinones. In our case, addition of 1 equiv. $\mathrm{SOCl}_{2}$ to the reaction increased the yield to $66 \%$ (entry 7). A limited solvent study of these conditions showed that THF gives the highest cis:trans ratio. The reaction proceeds also in EtOAc or $\mathrm{CH}_{3} \mathrm{CN}$. Furthermore, oxalyl chloride can be used in place of thionyl chloride. However, at least equiv. each of $\mathrm{ZnCl}_{2}$ and $\mathrm{SOCl}_{2}$ are necessary. With lower amounts, the reaction remained incomplete. The optimized reaction conditions give 9 in $c a .75 \%$ crude yield with 15:1 to 20:1 ratio. Recrystallization gives 9 in better than 50:1 cis: trans ratio and $c a .65 \%$ yield [12].

The use of at least 1 equiv. of $\mathrm{SOCl}_{2}$ with $\mathrm{N}-\mathrm{Cbz}-(\mathrm{L})$-alanine initially led us to

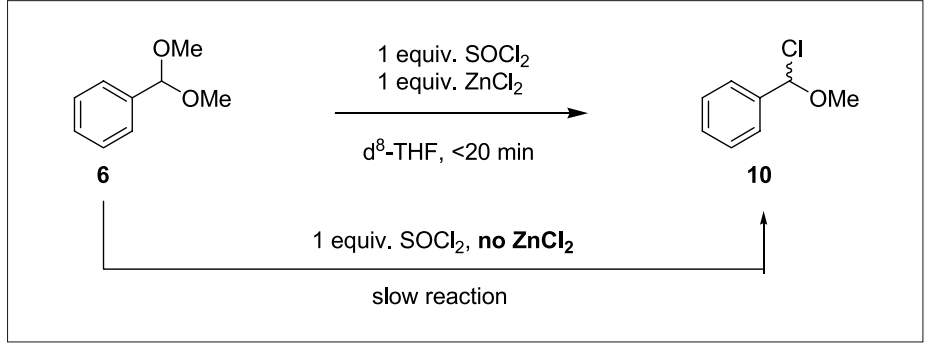

Scheme 5. Activation of 6 with thionyl chloride

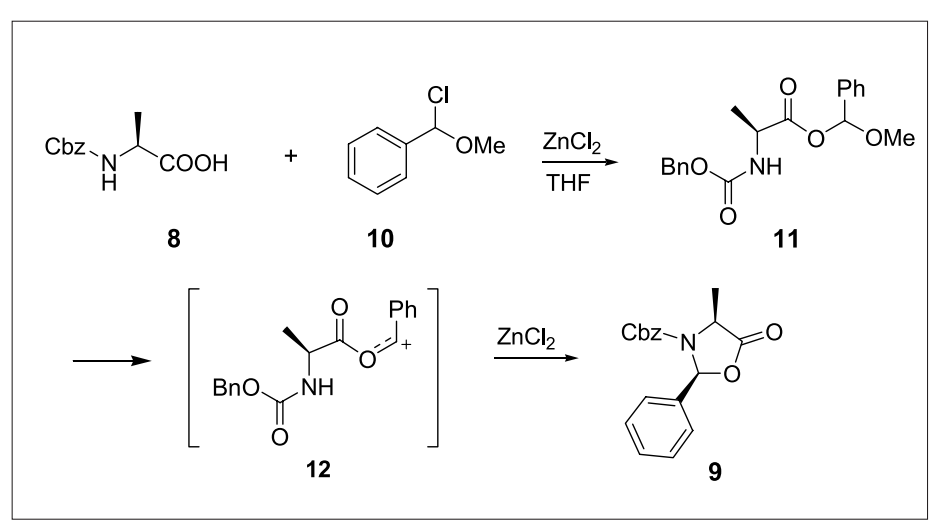

Scheme 6. Oxazolidinone via $\alpha$-chloroether/ $/ \mathrm{nCl}_{2}$

believe that the acid chloride of N-Cbz-(L)alanine could be an intermediate. However, ${ }^{1} \mathrm{H}-\mathrm{NMR}$ experiments in $\mathrm{d}_{8}$-THF showed a fast reaction, $<20 \mathrm{~min}$ at $\mathrm{rt}$, between $\mathrm{SOCl}_{2}$ and 6 in the presence of $\mathrm{ZnCl}_{2}$ to yield $\alpha$ chloro ether 10 (Scheme 5).

The corresponding formation of $\mathbf{1 0}$ in the absence of $\mathrm{ZnCl}_{2}$ is very slow, $c a$. $40 \%$ after $18 \mathrm{~h}$ at room temperature. Furthermore, when $\mathrm{ZnCl}_{2}$ is added to a mixture of $\mathrm{N}-\mathrm{Cbz}$-(L)-alanine, $\mathrm{SOCl}_{2}$ and benzaldehyde dimethyl acetal, $\mathbf{1 0}$ is observed before

Table 2. Cyclization experiments with different Lewis acids

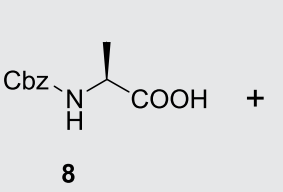

$\begin{array}{cc}\text { Entry } & \text { Lewis acid } \\ 1 & \mathrm{ZnCl}_{2} \\ 2 & \mathrm{ZnCl}_{2} \\ 3 & \mathrm{TiCl}_{4} \\ 4 & \mathrm{ZnBr}_{2}(2 \text { equiv. }) \\ 5 & \mathrm{ZnBr}_{2}(1 \text { equiv. }) \\ 6 & \mathrm{ZnCl}_{2}(2 \text { equiv. }) \\ 7 & \mathrm{ZnCl}_{2} / \mathrm{SOCl}_{2} \\ 8 & \mathrm{ZnCl}_{2} / \mathrm{SOCl}_{2}\end{array}$

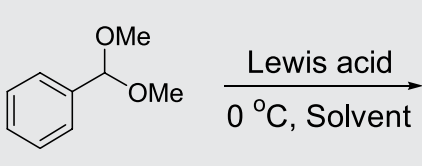

6

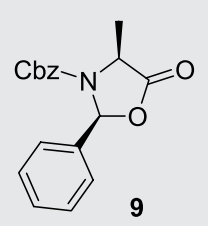

9 the appearance of any oxazolidinone (9) as determined by ${ }^{1} \mathrm{H}-\mathrm{NMR}$. Thus, in the presence of $\mathrm{ZnCl}_{2}, \mathbf{1 0}$ reacts with $\mathbf{8}$ to afford the cyclized product 9 (presumably through $\mathbf{1 1}$ and 12) as shown in Scheme 6.

From our early studies of this reaction we noted that a cis:trans ratio of 5:1 was common. This ratio was also obtained if pure cis-9 was treated with $\mathrm{ZnCl}_{2}$ in $\mathrm{CH}_{2} \mathrm{Cl}_{2}$ suggesting that $5: 1$ is the thermodynamic composition. Interestingly, we found that a 3:1 cis:trans mixture of 9 could be enriched to $8: 1$ by stirring with $\mathrm{ZnCl}_{2}$ in THF for 20 $\mathrm{h}$ at rt.

To clarify this behavior, we followed the reaction by ${ }^{1} \mathrm{H}-\mathrm{NMR}$. Surprisingly, the trans $\mathbf{9}$ was formed selectively in the very early stages of the reaction as identified by the chemical shift of $\mathrm{H}(2)$. The selective formation of the trans-diastereomer in the early stages of the reaction is also observed by HPLC sampling of the reaction mixture. With time, however, the cis-diasteromer becomes the predominant species and by the end of the reaction the ratio of cis:trans is ca. 9:1. This indicates that trans is the kinetic diastereomer and the thermodynamic composition in THF is ca. 9:1 (cis:trans).

After work-up, 9 is isolated as a 15:1 to 20:1 mixture of cis and trans diastereomers. Apparently, there is some kind of enrichment taking place after the cyclization is completed. The exact ratio varies somewhat between runs and seems to depend also on the scale of the reaction and the reaction temperature during aqueous quench. We 
reasoned that perhaps the minor diastereomer may be selectively hydrolyzed by acid released during the aqueous quench and that this could explain the improved ratios observed in the crude product. Therefore, a 5:1 cis:trans mixture of 9 was dissolved in THF and to this solution, a small amount of $\mathrm{ZnCl}_{2}$ and $\mathrm{SOCl}_{2}$ was added to mimic actual reaction conditions because these reagents are used in slight excess. This mixture was quenched with water slowly keeping the temperature below $10{ }^{\circ} \mathrm{C}$. Samples for HPLC taken during the quench confirmed that the trans diastereomer is hydrolyzed more rapidly than the cis.

Although this protocol to make 9 was amenable to scale-up, it suffered from the use of more than stoichiometric amounts of $\mathrm{ZnCl}_{2}$ and $\mathrm{SOCl}_{2}$ and also the fact that the crude material needed recrystallization to reach high diastereomeric purity.

\section{Cyclization Catalyzed by $\mathrm{ZnCl}_{2}$ or $\mathrm{SnCl}_{4}$}

Our previous work on imidazolidinones [9-11] had demonstrated the possibility of a crystallization-driven asymmetric transformation [22] process to provide a pure diastereomer from a thermodynamic mixture of cis:trans isomers for use as a template for subsequent alkylation. Our intention was to take advantage of this reaction feature in the oxazolidinone synthesis as well. We also wanted to explore the use of acid chlorides as substrates for the oxazolidinone formation, based on the literature precedent that acetyl chloride reacts with aromatic aldehydes to form $\alpha$-chlorobenzyl acetates in the presence of Lewis acids (e.g. $\mathrm{ZnCl}_{2}$ ) [23]. Our hypothesis was that the in situ generation of an acid chloride from a carbamate-protected amino acid followed by reaction with an aromatic aldehyde would afford an oxazolidinone directly.

However, acid chlorides from $\mathrm{N}$-acyl amino acids are difficult to prepare and are known to be unstable. Buckley et al. have shown that acid chlorides from $\mathrm{N}$-amides of amino acids undergo racemization via azlactone formation [24]. This reaction is much slower with N-carbamates [25] and it is known [24] that N-ethoxycarbonyl alanine can be converted to the corresponding acid chloride using oxalyl chloride/DMF without racemization.

Thus, treatment of $\mathrm{N}-i$-butyloxycarbonyl-(L)-alanine (13) in $\mathrm{CH}_{2} \mathrm{Cl}_{2}$ with catalytic DMF and 1 equiv. oxalyl chloride leads to the acid chloride $\mathbf{1 4}$ in quantitative yield. It can be isolated as a yellow oil or used directly in solution. Addition of benzaldehyde followed by a catalytic amount of solid $\mathrm{ZnCl}_{2}$ leads to the formation of oxazolidinone $15 \mathrm{c}$ in good yield as a thermodynamic mixture of cis and trans diastereomers in 85:15 ratio as outlined in Scheme 7.

We studied the formation of oxazolidi-

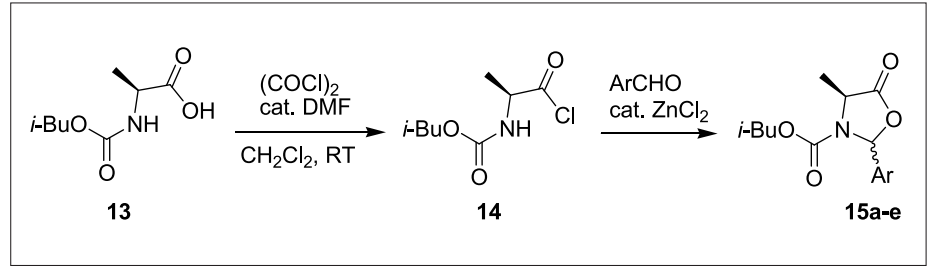

Scheme 7. Novel synthesis of oxazolidinones

nones from $\mathrm{N}$-methoxy and $\mathrm{N}-\mathrm{i}$-butyloxy carbamates and different aldehydes. From our work on the corresponding $\mathrm{N}$-amides, we knew that epimerization at the $\mathrm{C}(2)$ position readily takes place upon exposure to a variety of acidic reagents such as $\mathrm{ZnCl}_{2}$ in $\mathrm{CH}_{2} \mathrm{Cl}_{2}$ or $p$-toluenesulfonic acid in refluxing benzene. Thus, formation of a variety of oxazolidinones with $\mathrm{ZnCl}_{2}$ in $\mathrm{CH}_{2} \mathrm{Cl}_{2}$ established the equilibrium composition of cis and trans isomers and this is shown in Table 3.

The preference for the cis-diastereomer in $\mathbf{1 5}$ is thought to arise from $\mathrm{A}^{1,3}$-strain [26] with the $\mathrm{N}$-acyl substituent pointing in the opposite direction from the substituents in the 2- and 4-positions, thus slightly lowering the energy of the cis-isomer. In entry 5, the ratio of cis and trans is almost equal and this is likely due to the steric bulk of the 9-anthranyl substituent leading to a very small energy difference between the two isomers.

The attempts to obtain a crystalline oxazolidinone were successful with $\mathrm{N}-i$ butyloxy carbamate and 4'-biphenylcarboxaldehyde to give 15d, Table 3 , entry 4. In solution, the 85:15 ratio of cis- and trans-15d was observed. However, when the solvent was partially removed and the residue suspended in MTBE, an off-white solid could be filtered off which consisted

of pure $c i s-\mathbf{1 5 d}$ in $c a .82 \%$ yield. Analysis of the mother liquors showed minor amounts of cis and trans product in a 85:15 ratio, along with some unreacted carbamate and $\alpha, \alpha$-dichloromethyl biphenyl. The presence of an 85:15 ratio of cis- and trans-15d in the mother liquor is clear evidence that a crystallization-induced asymmetric transformation operates to provide pure cis-diastereomer.

A small survey of Lewis acids showed that $\mathrm{SnCl}_{4}$ gave the highest yield of $\mathbf{1 5 d}$ (Table 4). Using the optimized conditions the oxazolidinone template was isolated in $92 \%$ yield on kilogram scale.

The structure of $\mathbf{1 5 d}$ was confirmed by single crystal X-ray analysis and is shown in Fig. 1. The cis relationship of the 4-methyl and the 2-biphenyl substituents is therefore confirmed.

The reaction of $\mathrm{N}-i$-butyloxycarbonyl(L)-alanine and $(\mathrm{COCl})_{2}$ is rapid at room temperature and forms acid chloride $\mathbf{1 4}$ in quantitative yield as determined by ${ }^{1} \mathrm{H}$ NMR in $\mathrm{CD}_{2} \mathrm{Cl}_{2}$. No changes occur when ${ }^{13} \mathrm{C}$-labeled benzaldehyde $(\delta=192.6 \mathrm{ppm}$ for ${ }^{13} \mathrm{C}=\mathrm{O}$ ) is added to the acid chloride (Fig. 2, spectrum a). When $10 \mathrm{~mol} \% \mathrm{SnCl}_{4}$ is added to this mixture, a major unknown peak is observed at 83.4 ppm as well as new peaks at 89.3 and $89.5 \mathrm{ppm}$ corresponding to $\mathrm{C}(2)$ in cis-15c and trans-15c, respective-

Table 3. Equilibration ratios of different oxazolidinones

\begin{tabular}{ccccc|}
\hline Entry & $\mathbf{R}$ & Aldehyde & Cis:Trans & Product \\
\hline 1 & $\mathrm{Me}$ & $\mathrm{Ph}$ & $85: 15$ & $\mathbf{1 5 a}$ \\
2 & $\mathrm{Me}$ & 4'-biphenyl & $85: 15$ & $\mathbf{1 5 b}$ \\
3 & $i-\mathrm{Bu}$ & $\mathrm{Ph}$ & $85: 15$ & $\mathbf{1 5 c}$ \\
4 & $i-\mathrm{Bu}$ & 4'-biphenyl & $85: 15$ & $\mathbf{1 5 d}$ \\
5 & $i$-Bu & 9-anthranyl & $55: 45$ & $\mathbf{1 5 e}$ \\
\hline
\end{tabular}

Table 4. Influence of catalyst on the conversion to oxazolidinone $\mathbf{1 5 d}$

\begin{tabular}{|c|c|c|}
\hline Catalyst & Conversion & Cis:Trans \\
\hline $\mathrm{ZnCl}_{2}$ & $87 \%$ & $5: 1$ \\
\hline $\mathrm{SnCl}_{4}$ & $94 \%$ & $5: 1$ \\
\hline $\mathrm{TiCl}_{4}$ & $<10 \%$ & $3: 1$ \\
\hline $\mathrm{Ti}(i-\mathrm{PrO})_{4}$ & trace & - \\
\hline
\end{tabular}




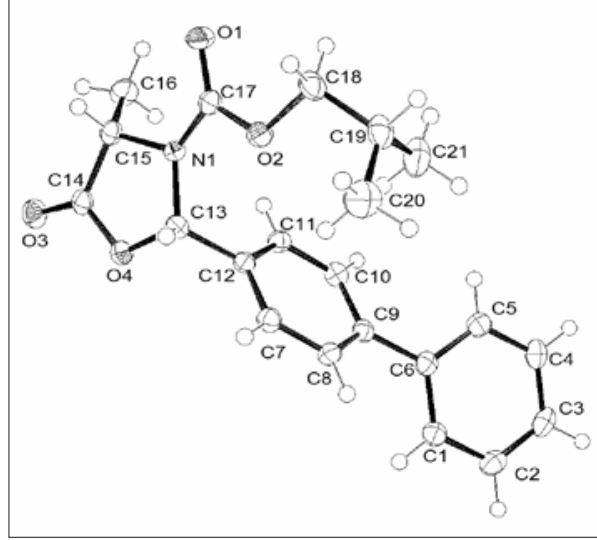

Fig. 1. Single crystal X-ray structure (ORTEP representation) for (L)-oxazolidinone (15d)

ly (Fig. 2, spectrum b). The peak at 83.4 ppm diminishes whereas the peaks at 89.3 and 89.5 from 15c increase over time (Fig. 2 , spectra $\mathrm{c}$ and $\mathrm{d}$ ).

We propose that the unknown species observed at $83.4 \mathrm{ppm}$ corresponds to an intermediate $\alpha$-chloro benzyl ester $\mathbf{1 6}$ as shown in Scheme 8 [27].

The main support for intermediate $\mathbf{1 6}$ comes from correlation to the ${ }^{13} \mathrm{C}-\mathrm{NMR}$ study of the analogous reaction with acetyl chloride (18) and ${ }^{13} \mathrm{C}$-labeled benzaldehyde in the presence of catalytic $\mathrm{SnCl}_{4}$ to give $\alpha$-chlorobenzyl acetate (19), as laid out in Scheme 8 . The signal for the benzylic carbon in $\mathbf{1 9}$ is readily observed at $82.9 \mathrm{ppm}$.

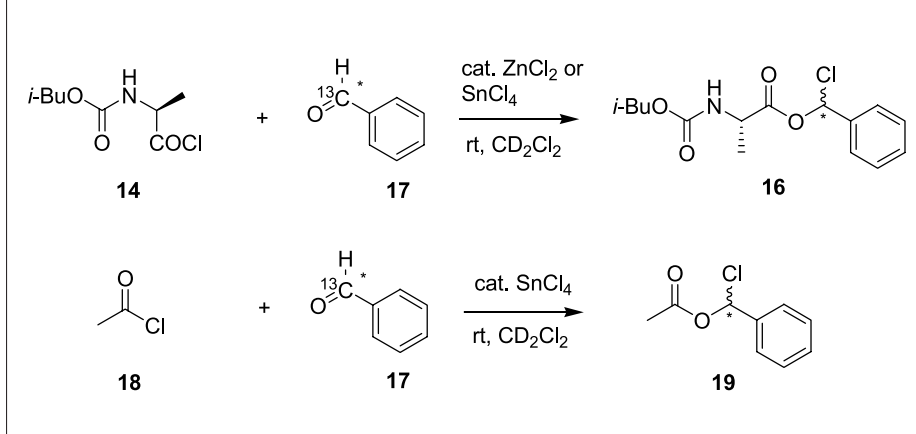

Scheme 8. Synthesis of ${ }^{13} \mathrm{C}$-labeled $\alpha$-chlorobenzyl esters

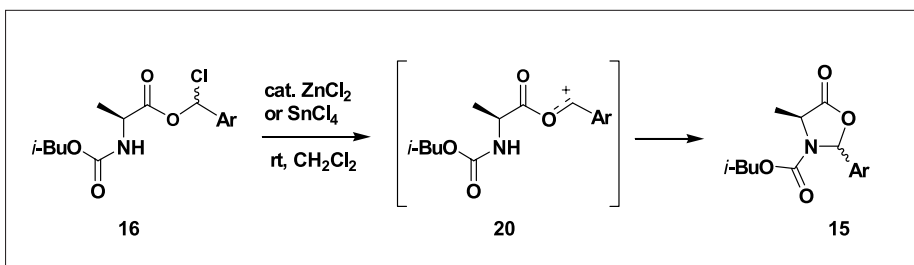

Scheme 9. Proposed mechanism for oxazolidinone formation

This is very close to the signal at $83.4 \mathrm{ppm}$ observed for the unknown intermediate (vide supra).

Unfortunately, the isolation of $\mathbf{1 6}$ is not possible since it undergoes rapid cyclization to the oxazolidinone. Additional qualitative evidence for an intermediate in the cyclization comes from ReactIR experiments. When benzaldehyde is added to

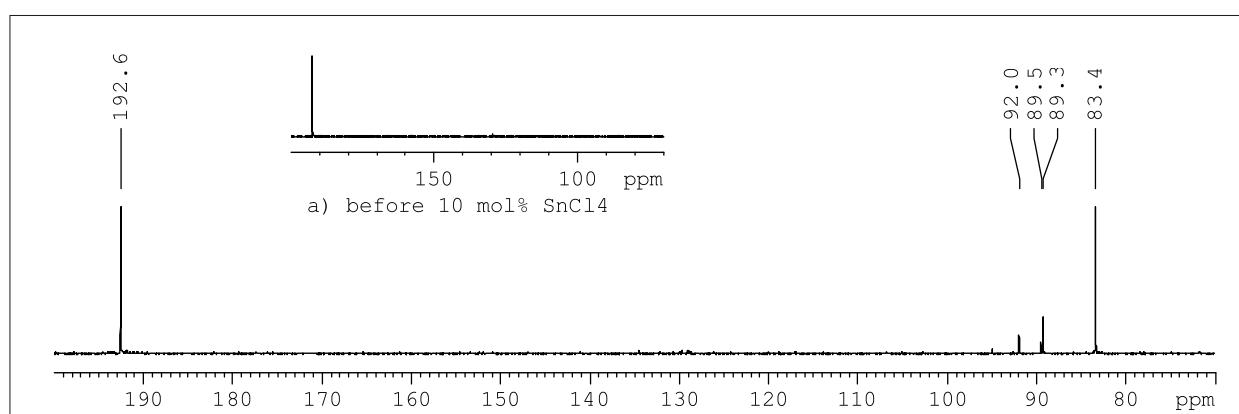

b) 2 minutes after $10 \mathrm{~mol} \% \mathrm{SnCl} 4$

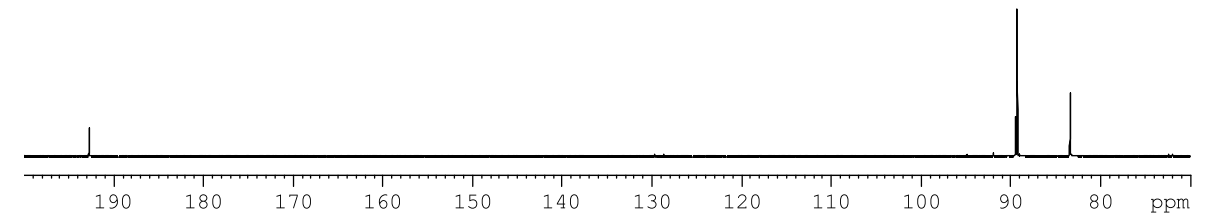

c) 30 minutes after $10 \mathrm{~mol} \% \mathrm{SnCl} 4$

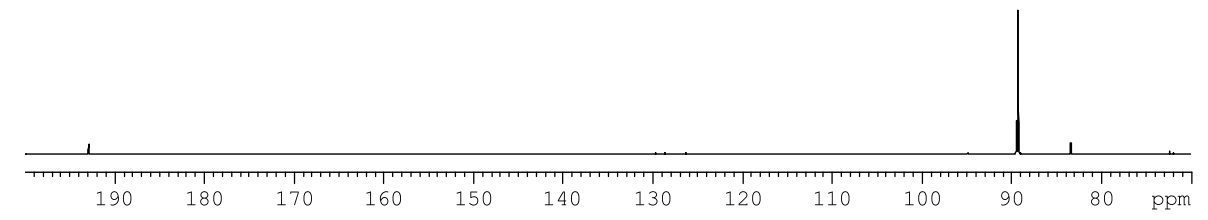

d) 60 minutes after $10 \mathrm{~mol} \% \mathrm{SnCl} 4$

Fig. 2. Formation of oxazolidinone 15a using ${ }^{13} \mathrm{C}$-labelled $\mathrm{PhCHO} .{ }^{13} \mathrm{C}$-spectra; a) before $10 \mathrm{~mol} \%$ $\mathrm{SnCl}_{4}$. b) 2 min after $10 \mathrm{~mol} \% \mathrm{SnCl}_{4}$. c) $30 \mathrm{~min} \mathrm{d)} 60 \mathrm{~min}$. a $\mathrm{CH}_{2} \mathrm{Cl}_{2}$ solution of the acid chloride in the presence of catalytic $\mathrm{SnCl}_{4}$, a new carbonyl resonance at $1800 \mathrm{~cm}^{-1}$ is observed which is attributed to the oxazolidinone product. The benzaldehyde signal at 1702 $\mathrm{cm}^{-1}$ disappears at $\mathrm{ca} .3$ times faster rate than the appearance of the oxazolidinone signal suggesting the formation of an intermediate which is transformed into the oxazolidinone product at a slightly slower rate. Scheme 9 shows the proposed mechanism for oxazolidinone formation.

\section{Alkylation of Oxazolidinones}

Alkylation of 15d is stereospecific and takes place from the face opposite the biphenyl moiety, leading via $\mathbf{2 1}$ to derivatives of 22 in $>98 \%$ ee as determined by chiral-phase HPLC (Scheme 10). In the procedure, LiHMDS is added at $-25^{\circ} \mathrm{C}$ to a mixture of electrophile and 15d. Alternatively, the enolate can be generated at $-78{ }^{\circ} \mathrm{C}$ followed by addition of the electrophile. The results were poorer when the enolate was first generated at $-25{ }^{\circ} \mathrm{C}$ followed by addition of electrophile, indicating that the enolate is stable at $-78{ }^{\circ} \mathrm{C}$ but not at $-25{ }^{\circ} \mathrm{C}$.

Crude oxazolidinone $\mathbf{2 1}$ is then treated with $\mathrm{MeOLi}$ in $\mathrm{MeOH}$ to make the methyl ester 22. This liberates the 4'-biphenylcarboxaldehyde [28] which is isolated during workup as its sodium bisulfite adduct via filtration and can subsequently be regenerated [29] for use in the synthesis of $\mathbf{1 5 d}$.

The scope of the alkylation is shown in Table 5. Activated allylic-type electrophiles generally give excellent yield of derivatives of 22. A non-activated alkyl electrophile 


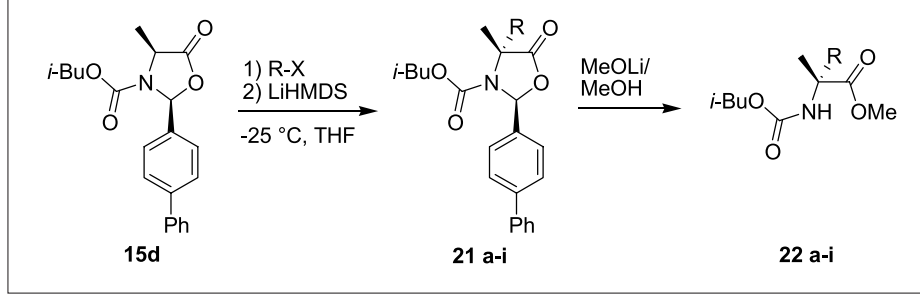

Scheme 10. Diastereoselective synthesis of $\alpha, \alpha^{\prime}$-aminoesters

Table 5. Alkylation/Transesterification of $\mathbf{1 5 d}$

Entry

(e.g. butyl bromide) gave lower yield as can be expected. However, addition of 1 equiv. DMPU to the enolate before addition of the $\mathrm{BuBr}$ increased the isolated yield to $70 \%$ over two steps [30].

\section{Summary}

In summary, three methods to synthesize enantiomerically pure oxazolidinones from (L)-alanine have been evaluated and a novel synthesis of a chiral oxazolidinone using a dynamic asymmetric transforma- tion has been demonstrated on kilogram scale. Alkylation of the oxazolidinone followed by hydrolysis leads to $\alpha$-substituted esters of (L)-alanine in >98-99\% ee.

\section{Experimental}

\section{General}

All melting points are uncorrected. ${ }^{1} \mathrm{H}$ and ${ }^{13} \mathrm{C}$ NMR spectra were obtained on Bruker spectrometers operating at 500/400 and $125 / 100 \mathrm{MHz}$, respectively. Elemental analysis were performed by QTI Analyses,
NJ. Enantiomeric ratios were determined on a Chiralcel OD column using hexanes/ isopropanol as eluent. Authentic samples of the opposite enantiomer were prepared in all cases. All chemicals were obtained from commercial sources and used as received unless otherwise noted. Anhydrous solvents from Aldrich were used directly.

\section{(S)-2-Isobutoxycarbonylamino- propionic Acid (13c) [31]}

(L)-Alanine (411 g, $4.61 \mathrm{~mol}, 1$ equiv.) was added to a 121 four-neck round bottom flask, fitted with mechanical stirrer, addition funnel and temperature probe. Water (3.42 1) was added and the resulting solution cooled to $10-15{ }^{\circ} \mathrm{C}$ with an ice/water bath. Solid NaOH (184.4 g, 4.61 mol, 1 equiv.) was added in portions to give a solution with $\mathrm{pH} 11-12$. The temperature rose to $c a .20^{\circ} \mathrm{C}$ with each portion of $\mathrm{NaOH}$. Dimethylaminopyridine (DMAP, $23 \mathrm{~g}$, 0.189 mol, 0.041 equiv.) was added and the reaction cooled back down to $c a .15^{\circ} \mathrm{C}$. To this solution was added $i$-butylchloroformate ( $688 \mathrm{ml}, 5.30 \mathrm{~mol}, 1.15$ equiv.) in one portion. The reaction was stirred vigorously and $30 \%$ aq. $\mathrm{NaOH}$ was added via the addition funnel at a rate to maintain the $\mathrm{pH}$ around 10-11. During the aq. $\mathrm{NaOH}$ addition the reaction temperature rose to 42 ${ }^{\circ} \mathrm{C}$ and was cooled down by addition of ice directly into the reaction mixture. A total of ca. $900 \mathrm{ml}$ of $30 \%$ aq. $\mathrm{NaOH}$ was added. Once the $\mathrm{pH}$ had stabilized at $\mathrm{pH}$ 10-11, the reaction was cooled to room temperature and stirred overnight.

The reaction solution was cooled to $2-3$ ${ }^{\circ} \mathrm{C}$ by addition of ice directly to the flask and the $\mathrm{pH}$ was then adjusted to 1-2 by addition of conc. $\mathrm{HCl}$. The resulting turbid reaction mixture was extracted with $\mathrm{CH}_{2} \mathrm{Cl}_{2}$ $(3 \times 1.5 \mathrm{l})$ and the combined organic layer was concentrated on a rotavap and dried further under high vacuum to afford $843 \mathrm{~g}$ of a white, waxy solid ( $96 \%$ yield).

Anal. calc. for $\mathrm{C}_{8} \mathrm{H}_{15} \mathrm{NO}_{4}, \mathrm{C} ; 50.78, \mathrm{H}$; 7.99; N; 7.40: Found: C; 50.92, H; 8.29, N; 7.19 .

${ }^{1} \mathrm{H}-\mathrm{NMR}$ and ${ }^{13} \mathrm{C}-\mathrm{NMR}$ data correlate well with published data [31].

\section{(2S,4S)-2-Biphenyl-4-yl-4-methyl-5- oxo-oxazolidine-3-carboxylic Acid Isobutyl Ester (15d)}

A 121 four-neck round bottom flask, fitted with mechanical stirrer, addition funnel, reflux condenser, argon inlet and temperature probe, was purged with argon for 30 min. N-i-Butyloxycarbonyl-(L)-alanine (641 g, 3.39 mol, 1 equiv.) was added to the flask and dissolved in $\mathrm{CH}_{2} \mathrm{Cl}_{2}(3.3 \mathrm{l})$. Dimethylformamide $(13.2 \mathrm{ml}, 0.17 \mathrm{~mol}$, 0.05 equiv.) was added, the mixture stirred at $200 \mathrm{rpm}$ and cooled to $7-8{ }^{\circ} \mathrm{C}$ in an ice/water bath. Once at that temperature, 
oxalyl chloride $(301.7 \mathrm{ml}, 3.46 \mathrm{~mol}, 1.02$ equiv.) was added in one portion via the addition funnel. A $1-2{ }^{\circ} \mathrm{C}$ temperature rise was observed along with the release of gas $\left(\mathrm{HCl}, \mathrm{CO}_{2}, \mathrm{CO}\right)$ from the reaction. The ice/water bath was removed and the solution stirred at ambient temperature for $5 \mathrm{~h}$ until all gas bubbling had ceased. Biphenylcarboxaldehyde (661 g, $3.46 \mathrm{~mol}, 1.02$ equiv.) was added as a solid in one portion to afford an orange solution. Within 5 min, a solution of $\mathrm{SnCl}_{4}(170 \mathrm{ml}, 1.0 \mathrm{M}$ in $\mathrm{CH}_{2} \mathrm{Cl}_{2}, 0.05$ equiv.) was added, leading to a red solution and a rise in temperature from 13 to $26{ }^{\circ} \mathrm{C}$ over $5-10 \mathrm{~min}$. The temperature stabilized and the solution was stirred at $25^{\circ} \mathrm{C}$ for $20 \mathrm{~h}$ with a slow argon purge to remove $\mathrm{HCl}$ gas formed during the reaction. The reaction mixture was then concentrated under reduced pressure until $\mathrm{ca} .11 \mathrm{CH}_{2} \mathrm{Cl}_{2}$ remained to afford a suspension. MTBE (1.9 1) was added and the suspension was stirred at ambient temperature for $c a .15 \mathrm{~h}$. The thick suspension was cooled to $2-3{ }^{\circ} \mathrm{C}$ with ice/water bath, stirred at that temperature for $2.5 \mathrm{~h}$ and then filtered on a medium frit Büchner funnel to afford an off-white solid. The solid was washed with a 11 portion of cold MTBE and dried on the frit under vacuum for $3 \mathrm{~h}$ to give $1.10 \mathrm{~kg}(92 \%)$ oxazolidinone product.

${ }^{1} \mathrm{H}-\mathrm{NMR},{ }^{13} \mathrm{C}-\mathrm{NMR}$ and combustion analysis data correlate well with those published [13].

\section{General Procedure for Alkylation of 15d}

The oxazolidinone template 15d (4 mmol) and the corresponding alkyl halide (4.2 mmol) were suspended in THF (12 $\mathrm{ml}$ ) under argon in a dry $50 \mathrm{ml}$ flask. The mixture was cooled to $-25{ }^{\circ} \mathrm{C}$ with a dry ice/acetone bath. LiHMDS (1.0 M in THF; $4.2 \mathrm{ml}$ ) was added slowly over 20 minutes via syringe. The mixture was stirred at -25 ${ }^{\circ} \mathrm{C}$ for $30 \mathrm{~min}$ and at room temperature for $3 \mathrm{~h}$ to afford an orange solution. Saturated $\mathrm{NH}_{4} \mathrm{Cl}(15 \mathrm{ml})$ was added and the mixture was diluted with EtOAc $(50 \mathrm{ml})$. The layers were separated and the aqueous layer was extracted with EtOAc $(20 \mathrm{ml})$. The combined organic layer was washed with brine $(30 \mathrm{ml})$ and dried over $\mathrm{MgSO}_{4}$. Evaporation of the solvent afforded the crude alkylation product as an oil.

The crude alkylation product $(\sim 4$ mmol) was dissolved in dry $\mathrm{MeOH}$ (16 $\mathrm{ml}$ ) and $\mathrm{MeOLi}(4.4 \mathrm{ml}, 1.0 \mathrm{M}$ in $\mathrm{MeOH}$ ) was added. The solution stirred at room temperature until TLC indicated disappearance of starting material (1-3 h). A mixture of saturated aqueous $\mathrm{NaHSO}_{3}$ $(30 \mathrm{ml})$ and $\mathrm{CH}_{2} \mathrm{Cl}_{2}(40 \mathrm{ml})$ was added. A white precipitate formed and the mixture was stirred at room temperature for ca. $1 \mathrm{~h}$ after which the solid was filtered off. The filtrate layers were separated and the aqueous phase extracted with $\mathrm{CH}_{2} \mathrm{Cl}_{2}$ $(30 \mathrm{ml})$. The combined organic layer was washed with water $(50 \mathrm{ml})$, brine $(50 \mathrm{ml})$ and dried $\left(\mathrm{MgSO}_{4}\right)$ to afford the methyl ester as a yellow oil after evaporation of the solvent. The methyl esters were purified by flash chromatography on silica gel using EtOAc/hexanes.

\section{(R)-2-Isobutoxycarbonylamino-2- methyl-pent-4-enoic Acid Methyl Ester (22a)}

Flash chromatography on silica gel using $15 \% \mathrm{EtOAc/hexanes} \mathrm{gave} \mathrm{a} \mathrm{light} \mathrm{yel-}$ low oil (86\% over two steps). ${ }^{1} \mathrm{H}-\mathrm{NMR}$ $\left(\right.$ DMSO$\left.^{6} \mathrm{~d}^{6}\right): 7.48$ (br s, $\left.1 \mathrm{H}\right)$, 5.65-5.74 (m, $\mathrm{J}=7.5,9.4,18.0 \mathrm{~Hz}, 1 \mathrm{H}), 5.08(\mathrm{dd}, \mathrm{J}=$ 9.4,18.0, 2H), 3.68-3.76 (m, 2H), 3.59 (s, $3 \mathrm{H}), 2.59$ (dd, J = 7.0, $13.5 \mathrm{~Hz}, 1 \mathrm{H}), 2.39$ (dd, J = 7.0, $13.5 \mathrm{~Hz}, 1 \mathrm{H}), 1.80-1.84(\mathrm{~m}$ $1 \mathrm{H}), 1.30$ (s, 3H), 0.88 (d, J = 6.5 Hz, 6H). ${ }^{13} \mathrm{C}-\mathrm{NMR}$ (DMSO-d $\left.{ }^{6}\right): 173.04,154.32$, 131.90, 117.87, 68.72, 57.27, 50.91, 40.04 26.77, 21.36, 17.92. LCMS: $\mathrm{m} / \mathrm{z}=244.1$ $(\mathrm{M}+\mathrm{H})^{+}$. Anal. calc. for $\mathrm{C}_{12} \mathrm{H}_{21} \mathrm{NO}_{4}, \mathrm{C}$; 59.24, H; 8.70; N; 5.76: Found: C; 59.19, $\mathrm{H} ; 8.73, \mathrm{~N} ;$ 5.72. Enantiomeric purity; $>99 \%$ ee.

\section{(E)-(R)-2-Isobutoxycarbonylamino- 2-methyl-5-phenyl-pent-4-enoic Acid Methyl Ester (22b)}

Flash chromatography on silica gel using $15 \%$ EtOAc/hexanes gave a colorless oil (80\% over two steps). ${ }^{1} \mathrm{H}-\mathrm{NMR}\left(\mathrm{CDCl}_{3}\right)$ : $7.22-7.34(\mathrm{~m}, 5 \mathrm{H}), 6.45(\mathrm{~d}, \mathrm{~J}=16 \mathrm{~Hz}, 1 \mathrm{H})$ $6.04(\mathrm{dt}, \mathrm{J}=7,16 \mathrm{~Hz}, 1 \mathrm{H}), 3.84(\mathrm{~m}, 2 \mathrm{H})$, 3.77 (s, 3H), 2.95 (br, 1H), 2.72-2.78 (dd, $\mathrm{J}=7,14 \mathrm{~Hz}, 1 \mathrm{H}), 1.90(\mathrm{~m}, \mathrm{~J}=7 \mathrm{~Hz}, 1 \mathrm{H})$, $1.62(\mathrm{~s}, 3 \mathrm{H}), 0.91(\mathrm{~d}, \mathrm{~J}=7 \mathrm{~Hz}, 6 \mathrm{H}) .{ }^{13} \mathrm{C}$ NMR $\left(\mathrm{CDCl}_{3}\right): 174.3,136.9,134.3,128.5$, $127.5,126.2,123.6,70.84,59.74,52.69$, 40.47, 28.00, 23.35, 19.02. LCMS: $\mathrm{m} / \mathrm{z}=$ $320.3(\mathrm{M}+\mathrm{H})^{+}$. Anal. calc. for $\mathrm{C}_{18} \mathrm{H}_{25} \mathrm{NO}_{4}$ C; 67.69, H; 7.89; N; 4.39: Found: C; 67.60, $\mathrm{H} ;$ 7.90, N; 4.28. Enantiomeric purity; $98.9 \%$ ee.

\section{(R)-2-Isobutoxycarbonylamino-2- methyl-3-phenyl-propionic Acid Methyl Ester (22c)}

Flash chromatography on silica gel using $10 \% \mathrm{EtOAc/hexanes} \mathrm{gave} \mathrm{a} \mathrm{light} \mathrm{yel-}$ low oil (93\% over two steps). ${ }^{1} \mathrm{H}-\mathrm{NMR}$ $\left(\mathrm{CDCl}_{3}\right): 7.22-7.26(\mathrm{~m}, 3 \mathrm{H}), 7.03-7.06(\mathrm{~m}$, 2H), 5.36 (br, 1H), 3.84-3.93 (m, 2H), 3.73 (s, 3H), 3.93 (bd, 1H), 3.18 (d, J = $14 \mathrm{~Hz}$, $1 \mathrm{H}), 1.89-1.96(\mathrm{~m}, \mathrm{~J}=7 \mathrm{~Hz}, 1 \mathrm{H}), 1.61(\mathrm{~s}$, 3H), 0.92-0.94 (d, J = 7 Hz, 6H). ${ }^{13} \mathrm{C}-\mathrm{NMR}$ $\left(\mathrm{CDCl}_{3}\right): 174.18,155.12,136.21,129.92$, 128.22, 126.92, 70.83, 60.60, 52.56, 41.74 28.01, 23.63, 19.02. LCMS: $\mathrm{m} / \mathrm{z}=294.1$ $(\mathrm{M}+\mathrm{H})^{+}$. Anal. calc. for $\mathrm{C}_{16} \mathrm{H}_{23} \mathrm{NO}_{4}, \mathrm{C}$; 65.51, H; 7.70; N; 4.77: Found, C; 65.52, $\mathrm{H} ; 7.84, \mathrm{~N} ;$ 4.72. Enantiomeric purity; $>99 \%$ ee.
(R)-2-Isobutoxycarbonylamino-3-(3methoxy-phenyl)-2-methyl-propionic Acid Methyl Ester (22d)

Flash chromatography on silica gel using $10 \% \mathrm{EtOAc/hexanes} \mathrm{gave} \mathrm{a} \mathrm{color-}$ less oil (70\% over two steps). ${ }^{1} \mathrm{H}-\mathrm{NMR}$ $\left(\mathrm{CDCl}_{3}\right)$ : 7.14-7.26 (m, 1H), 6.75-7.79 (m, 1H), 6.59-6.65 (m, 2H), $5.41(\mathrm{br}, 1 \mathrm{H})$, 3.84-3.89 (m, 2H), 3.75 (s, 3H), 3.36 (bd, $1 \mathrm{H}), 3.16(\mathrm{~d}, \mathrm{~J}=14 \mathrm{~Hz}, 1 \mathrm{H}), 1.88-1.94(\mathrm{~m}$, $\mathrm{J}=7 \mathrm{~Hz}, 1 \mathrm{H}), 1.62(\mathrm{~s}, 3 \mathrm{H}), 0.93(\mathrm{~d}, \mathrm{~J}=7$ $\mathrm{Hz}, 6 \mathrm{H}) .{ }^{13} \mathrm{C}-\mathrm{NMR}\left(\mathrm{CDCl}_{3}\right): 174.2,159.4$, $155.1,137.7,129.2,122.2,115.7,112.3$, $70.86,60.57,55.06,52.62,41.76,27.98$, 23.71, 19.03. LCMS: $\mathrm{m} / \mathrm{z}=324.3(\mathrm{M}+\mathrm{H})^{+}$. Anal. calc. for $\mathrm{C}_{17} \mathrm{H}_{25} \mathrm{NO}_{5}, \mathrm{C} ; 63.14, \mathrm{H}$; 7.79; $\mathrm{N} ; 4.33$ : Found, C; 63.12, H; 7.76, N; 4.29. Enantiomeric purity; $>99 \%$ ee.

\section{(R)-3-(4-Bromo-phenyl)-2-isobu- toxycarbonylamino-2-methyl-propi- onic Acid Methyl Ester (22e)}

Flash chromatography on silica gel using $20 \% \mathrm{EtOAc/hexanes} \mathrm{gave} 1.44 \mathrm{~g}$ (97\% over two steps) slightly greenish oil. ${ }^{1} \mathrm{H}-\mathrm{NMR}$ $\left(\mathrm{CDCl}_{3}\right): 7.37(\mathrm{~d}, \mathrm{~J}=8.3 \mathrm{~Hz}, 2 \mathrm{H}), 6.92(\mathrm{~d}$, $\mathrm{J}=8.3 \mathrm{~Hz}, 2 \mathrm{H}), 5.35$ (br, 1H), 3.89-3.92 (m, 1H), 3.82-3.86 (m, 1H), $3.75(\mathrm{~s}, 3 \mathrm{H})$, 3.40 (bd, J = $13 \mathrm{~Hz}, 1 \mathrm{H}), 3.15$ (d, J = 13 $\mathrm{Hz}, 1 \mathrm{H}), 1.88-1.97(\mathrm{~m}, 1 \mathrm{H}), 1.60(\mathrm{~s}, 3 \mathrm{H})$, $0.93(\mathrm{~d}, \mathrm{~J}=7 \mathrm{~Hz}, 6 \mathrm{H}) .{ }^{13} \mathrm{C}-\mathrm{NMR}\left(\mathrm{CDCl}_{3}\right)$ : $171.84,152.94,133.24,129.48,129.23$, $118.90,68.85,58.42,50.57,38.85,25.93$, 21.65, 16.92. LCMS: $\mathrm{m} / \mathrm{z}=372.8(\mathrm{M}+\mathrm{H})^{+}$. Anal. calc. for $\mathrm{C}_{16} \mathrm{H}_{22} \mathrm{BrNO}_{4}, \mathrm{C} ; 51.62, \mathrm{H}$; 5.96; N; 3.76: Found, C; 51.57, H; 5.88, N; 3.70. Enantiomeric purity; $>99 \%$ ee.

\section{(R)-2-Isobutoxycarbonylamino-2- methyl-hexanoic Acid Methyl Ester (22f)}

The oxazolidinone template $(4 \mathrm{mmol})$ was suspended in THF (12 ml) under argon in a dry $50 \mathrm{ml}$ flask. The mixture was cooled to $-35{ }^{\circ} \mathrm{C}$ and LiHMDS $(1.0 \mathrm{M}$ in THF; $4.2 \mathrm{ml}, 1.05$ equiv.) was added slowly over 5 min via syringe to afford a yellow solution that was stirred for $30 \mathrm{~min}$ at -35 ${ }^{\circ} \mathrm{C}$. DMPU (4 mmol, 1 equiv.) was added and the solution stirred another $30 \mathrm{~min} . n$ $\mathrm{BuBr}$ (4.2 mmol, 1.05 equiv.) was added and the solution was allowed to reach $\mathrm{rt}$ over $4 \mathrm{~h}$. See general experimental procedure for work-up and hydrolysis/esterification. Flash chromatography on silica gel using $10 \% \mathrm{EtOAc} / \mathrm{hexanes}$ gave $0.73 \mathrm{~g}$ light yellow oil (70\% over two steps). ${ }^{1} \mathrm{H}-\mathrm{NMR}$ $\left(\mathrm{CDCl}_{3}\right): 5.45$ (br, $\left.1 \mathrm{H}\right), 3.81(\mathrm{~d}, \mathrm{~J}=6.6 \mathrm{~Hz}$, 2H), 3.75 (s, 3H), 2.09 (br, 1H), 1.88 (m, J $=6.7 \mathrm{~Hz}, 1 \mathrm{H}), 1.70-1.81(\mathrm{~m}, 1 \mathrm{H}), 1.56(\mathrm{~s}$, $3 \mathrm{H}), 1.17-1.34(\mathrm{~m}, 3 \mathrm{H}), 0.98-1.12(\mathrm{~m}, 1 \mathrm{H})$, $0.91(\mathrm{~d}, \mathrm{~J}=6.7 \mathrm{~Hz}, 6 \mathrm{H}), 0.87(\mathrm{t}, \mathrm{J}=6.9 \mathrm{~Hz}$, $3 \mathrm{H}) .{ }^{13} \mathrm{C}-\mathrm{NMR}\left(\mathrm{CDCl}_{3}\right): 175.17,155.25$, 70.90, 60.05, 52.76, 37.02, 28.20, 26.40, 23.57, 22.76, 19.21, 14.09. LCMS: $\mathrm{m} / \mathrm{z}=$ $260.2(\mathrm{M}+\mathrm{H})^{+}$. Anal. calc. for $\mathrm{C}_{13} \mathrm{H}_{25} \mathrm{NO}_{4}$, C; 60.21, H; 9.72; N; 5.40: Found: C; 60.00, 
$\mathrm{H} ;$ 9.83, N; 5.17. Enantiomeric purity; $>99 \%$ ee.

\section{(R)-2-Isobutoxycarbonylamino-2- methyl-3-(4-pyrimidin-5-yl-phenyl)- propionic Acid Methyl Ester (22g)}

The alkylation reaction was stirred at $-25^{\circ} \mathrm{C}$ for $16 \mathrm{~h}$ before warming to rt. Flash chromatography on silica gel using $35 \%$ EtOAc/hexanes gave a slightly greenish solid (67\% over two steps). ${ }^{1} \mathrm{H}-\mathrm{NMR}$ (CD$\left.\mathrm{Cl}_{3}\right): 9.11(\mathrm{~s}, 1 \mathrm{H}), 8.86(\mathrm{~s}, 2 \mathrm{H}), 7.42(\mathrm{~d}, \mathrm{~J}=$ $8.3 \mathrm{~Hz}, 2 \mathrm{H}), 7.17$ (d, J = 8.3 Hz, 2H), 5.55 (br, 1H), 3.87-3.91 (m, 1H), 3.80-3.84 (m, 1H), 3.75 (s, 3H), 3.47 (bd, J = $12 \mathrm{~Hz}, 1 \mathrm{H}$ ), $3.25(\mathrm{~d}, \mathrm{~J}=13 \mathrm{~Hz}, 1 \mathrm{H}), 1.85-1.94(\mathrm{~m}, 1 \mathrm{H})$, $1.60(\mathrm{~s}, 3 \mathrm{H}), 0.90(\mathrm{~d}, \mathrm{~J}=7 \mathrm{~Hz}, 6 \mathrm{H}) .{ }^{13} \mathrm{C}-$ NMR $\left(\mathrm{CDCl}_{3}\right)$ : 173.69, 157.04, 154.79, $154.36,137.26,133.55,132.47,130.70$, $126.36,70.58,60.23,52.33,40.83,27.70$, 23.46, 18.67. LCMS: $\mathrm{m} / \mathrm{z}=372.8(\mathrm{M}+\mathrm{H})^{+}$. Anal. calc. for $\mathrm{C}_{20} \mathrm{H}_{25} \mathrm{~N}_{3} \mathrm{O}_{4}, \mathrm{C} ; 64.67, \mathrm{H}$; 6.78; N; 11.31: Found: C; 64.49, H; 6.62, $\mathrm{N} ; 11.18$. Enantiomeric purity; $>99 \%$ ee.

\section{(R)-2-Isobutoxycarbonylamino-2- methyl-3-(4-trifluoromethoxy-phe- nyl)-propionic Acid Methyl Ester (22h)}

Flash chromatography on silica gel using $10 \% \mathrm{EtOAc/hexanes} \mathrm{gave} 1.36 \mathrm{~g} \mathrm{(90 \%}$ over two steps) slightly greenish oil. ${ }^{1} \mathrm{H}$ NMR (DMSO-d $\left.{ }^{6}\right): 7.44$ (s, 1H), 7.27 (d, J $=7.6 \mathrm{~Hz}, 2 \mathrm{H}), 7.21(\mathrm{~d}, \mathrm{~J}=8.1 \mathrm{~Hz}, 2 \mathrm{H})$, $3.82(\mathrm{~m}, 1 \mathrm{H}), 3.74(\mathrm{~m}, 1 \mathrm{H}), 3.61(\mathrm{~s}, 3 \mathrm{H})$, $3.31(\mathrm{~d}, \mathrm{~J}=13 \mathrm{~Hz}, 1 \mathrm{H}), 3.00(\mathrm{~d}, \mathrm{~J}=13.9$ $\mathrm{Hz}, 1 \mathrm{H}), 1.86$ (m, 1H), 1.21 (s, 3H), 0.90 $(\mathrm{d}, \mathrm{J}=6.7 \mathrm{~Hz}, 6 \mathrm{H}) .{ }^{13} \mathrm{C}-\mathrm{NMR}\left(\mathrm{DMSO}-\mathrm{d}^{6}\right)$ : $175.62,156.93,148.84,137.45,133.81$, 121.96, $121.70(\mathrm{JC}-\mathrm{F}=254 \mathrm{~Hz}), 71.38$, 60.29, 53.54, 41.54, 29.26, 23.92, 20.39. LCMS: $\mathrm{m} / \mathrm{z}=378.3(\mathrm{M}+\mathrm{H})^{+}$. Anal. calc. for $\mathrm{C}_{17} \mathrm{H}_{22} \mathrm{~F}_{3} \mathrm{NO}_{5}, \mathrm{C} ; 54.11, \mathrm{H} ; 5.88 ; \mathrm{N}$; 3.71: Found: $\mathrm{C} ; 54.25, \mathrm{H} ; 6.12, \mathrm{~N} ; 3.70$. Enantiomeric purity; $>99 \%$ ee.

\section{Acknowledgements}

Assistance with the single-crystal X-ray determination from Dr. Andre White is much appreciated.

Received: June 20, 2006
[1] a) R.M. Williams, 'Synthesis of Optically Active $\alpha$-Amino Acids', Organic Chemistry Series, Vol. 7, Eds. J.E. Baldwin, P.D. Magnus, Pergamon Press, Oxford 1989; b) H. Heimgartner, Angew. Chem. Int. Ed. Engl. 1991, 30, 238-264.

[2] K. Last-Barney, W. Davidson, M. Cardozo, L.L. Frye, C.A. Grygon, J.L. Hopkins, D.D. Jeanfavre, S. Pav, C. Qian, J.M. Stevenson, L. Tong, R. Zindell, T.A. Kelly, J. Am. Chem. Soc. 2001, 123, 5643-5650.

[3] T.A. Kelly, D.D. Jeanfavre, D.W. McNeil, J. Woska, P.L. Reilly, E.A. Mainolfi, K.M. Kishimoto, G.H. Nabozny, R. Zinter, B.J. Bormann, R.J. Rothlein, Immunol. 1999, 163, 5173

[4] a) C. Cativiela, M.D. Diaz-de-Villegas, Tetrahedron Asymmetry 1998, 9, 35173599; b) R.O. Duthaler, Tetrahedron 1994, 50, 1539-1650; c) T. Wirth, Angew. Chem. Int. Ed. Engl. 1997, 36, 225-227.

[5] a) U. Schöllkopf, W. Hartwig, U. Groth, K.O. Westphalen, Liebigs Ann. Chem. 1981, 696; b) U. Schöllkopf, U. Groth, K.-O. Westphalen, C. Deng, Synthesis 1981, 969 971. c) U. Schöllkopf, Tetrahedron 1983 , 39, 2085-2091 and references cited therein. See also J. Chen, S.P. Corbin, N.J. Holman, Org. Process Res. Dev. 2005, 9, 185-187.

[6] a) R.M. Williams, M.-N. Im, J. Am. Chem. Soc. 1991, 113, 9276-9286; b) R.M. Williams, M.-N. Im, Tetrahedron Lett. 1988 , 29, 6075-6078; c) P.J. Sinclair, D. Zhai, J. Reibenspies, R.M. Williams, J. Am. Chem. Soc. 1986, 108, 1103-1104; d) R.M. Williams, in 'Advances in Asymmetric Synthesis', Ed. A. Hassner, JAI Press, Greenwich, CT, 1995; Vol 1, pp 45-94 and references cited therein

[7] a) D. Seebach, A. Fadel, Helv. Chim Acta 1985, 68, 1243-1250; b) R. Naef, D. Seebach, Helv. Chim. Acta 1985, 68, 135-143.

[8] D. Seebach, A.R. Sting, M. Hoffmann, Angew. Chem. Int. Ed. Engl. 1996, 35, 2708-2748 and references cited therein.

[9] N. Yee, Org. Lett. 2000, 2, 2781-2783.

[10] R.P. Frutos, S. Stehle, L. Nummy, N. Yee, Tetrahedron Asymmetry 2001, 12, 101104.

[11] N. Yee, L.J. Nummy, R.P. Frutos, J.J. Song, E. Napolitano, D.P. Byrne, P.-J. Jones, V.
Farina, Tetrahedron Asymmetry 2003, 14, 3495-3501.

[12] S.R. Kapadia, D.M. Spero, M. Eriksson, J. Org. Chem. 2001, 66, 1903-1905.

[13] E. Napolitano, V. Farina, Tetrahedron Lett. 2001, 42, 3231-3234.

[14] A. Fadel, J. Salaün, Tetrahedron Lett. 1987, 28, 2243-2246.

[15] E. Altmann, K. Nebel, M. Mutter, Helv Chim. Acta 1991, 74, 800-806.

[16] K. Nebel, M. Mutter, Tetrahedron 1988, 44, 4793-4796.

[17] A. Alonso, S.G. Davis, A.S. Elend, J.L. Haggit, J. Chem. Soc., Perkin Trans. 1 1998, 257-264.

[18] S. Karady, J.S. Amato, L.M. Weinstock, Tetrahedron Lett. 1984, 25, 4337-4340.

[19] H. Cheng, P. Keitz, J.B. Jones, J. Org. Chem. 1994, 59, 7671-7676.

[20] W.D. Shrader, C.K. Marlowe, Bioorg.\& Med. Chem. Lett. 1995, 5, 2207-2210.

[21] F. Micheel, W. Meckstroth, Chem. Ber. 1959, 92, 1675-1679.

[22] N.G. Anderson, Org. Process Res. Dev. 2005, 9, 800-813 and references therein.

[23] M. Neuenschwander, P. Bigler, K. Christen, R. Isell, R. Kyburz, H. Mühle, Helv. Chim. Acta 1978, 61, 2047-2058.

[24] T.F. Buckley III, H. Rapoport, J. Am. Chem. Soc. 1981, 103, 6157-6160.

[25] J.H. Jones, M.J. Witty, J. Chem. Soc., Perkin Trans. 1 1979, 3203-3206.

[26] R.W. Hoffmann, Chem. Rev. 1989, 89, 1841-1860.

[27] Only one peak is observed although 16 should be present as two diastereomers. It is possible that the two signals overlap given the closeness of the signals from $\mathrm{C}(2)$ in cis- and trans-15c.

[28] This material is commercially available on metric ton scale for less than $\$ 50 / \mathrm{kg}$. In comparison, the price for research amounts is about $\$ 10 / \mathrm{g}$.

[29] D.P. Kjell, B.J. Slattery, M.J. Semo, $J$. Org. Chem. 1999, 64, 5722-5724.

[30] Only $33 \%$ yield over two steps was obtained in the absence of DMPU.

[31] R.A. Aitken, N. Karodia, T. Massil, R.J. Young, J. Chem. Soc., Perkin Trans. 1 2002, 533-541. 